\title{
PERANCANGAN SISTEM INFORMASI PERIZINAN BERBASIS WEB PADA DINAS PENANAMAN MODAL DAN PELAYANAN TERPADU SATU PINTU KABUPATEN PULAU MOROTAI
}

\section{THE DESIGN OF WEB-BASED LICENSING INFORMATION SYSTEM AT INVESTMENT AND ONE-STOP INTEGRATED SERVICE OFFICE MOROTAI ISLAND}

\author{
Miswar Papuangan ${ }^{1}$, Muamar Latowo ${ }^{2}$, Munazat Salmin ${ }^{3}$ \\ ${ }^{12}$ Program Studi Teknik Informatika, Fakultas Teknik \\ Universitas Pasifik Morotai \\ ${ }^{3}$ Program Studi Teknik Informatika, Fakultas Teknik \\ Universitas Khairun \\ miswarpapuangan@gmail.com
}

\begin{abstract}
Abstrak
Penyediaan pelayanan publik merupakan suatu kewajiban yang harus dilakukan pemerintah sebagai penyelenggaran negara, sehingga perlu adanya prosedur yang memadai untuk mempermudah masyarakat dalam mengurus pembuatan izin. Permohonan perizinan pada DPMPTSP masih bersifat konvensional sehingga tentunya membutuhkan banyak biaya dan tenaga dalam melakukan pengurusan perizinan. Perancangan sistem informasi perizinan berbasis web pada dinas penanaman modal dan pelayanan terpadu satu pintu kabupaten pulau morotai menggunakan metode perancangan sistem evolusioner. Metode evolusioner digunakan berdasarkan pada ide untuk mengembangkan implementasi awal, kemudian memperlihatkan sistem awal kepada pengguna untuk dikomentari. Pengujian sistem menggunakan white box testing. White box testing merupakan uji kasus yang menggunakan struktur kontrol yang dijelaskan sebagai bagian dari perancangan perangkat komponen untuk menghasilkan uji kasus. Perancangan sistem informasi perizinan menghasilkan sistem yang dapat meminimalisir kesalahan-kesalahan keterlambatan yang dilakukan dan lebih fleksibel untuk digunakan dengan menunjukan sistem mampu menghasiilkan jumlah cyclomatic coplexity $=44$, region $=44$, dan independent path $=44$.
\end{abstract}

Kata Kunci: Sistem Informasi, Perizinan, Web.

\begin{abstract}
The provision of public services is a necessity that must be carried out by the government as the organization of the state so that adequate procedures are needed to facilitate the community in the process of making permits. Permit
\end{abstract}


applications at DPMPTSP are still conventional, so of course, it requires a lot of money and energy in carrying out-licensing arrangements. The design of webbased licensing information systems at investment and one-stop integrated services office morotai island using the evolutionary system design method. The evolutionary method is used based on the idea of developing the initial implementation, then exposing the initial system to the user for comments. System testing using white box testing. White box testing is a test case that uses a control structure that is explained as part of the component device design to produce test cases. The design of the licensing information system produces a system that can minimize the mistakes made late and more flexible to use by showing the system can produce the number of cyclomatic complexity $=44$, region $=44$, and independent path $=44$.

\section{Keywords: Information Systems, Licensing, Web.}

\section{PENDAHULUAN}

Perkembangan globalisasi saat ini terus meningkat dan bergulir. Sistem pemerintahan ditiap Negara harus dapat dituntut peka dan mampu untuk mengatasi semua pekerjaan yang diberikan.

Pelayanan publik merupakan salah satu bagian penting yang menjadi perhatian pemerintah. Penyediaan pelayanan publik merupakan suatu kewajiban yang harus dilakukan pemerintah sebagai penyelenggara negara, sehingga perlu adanya prosedur yang memadai untuk mempermudah masyarakat dalam mengurus pembuatan izin. Salah satu pelayanan publik yang paling sering diakses oleh masyarakat adalah pelayanan perizinan. seperti yang diketahui bahwa masyarakat tidak akan pernah terlepas dari perizinan.

Sistem pembuatan izin di dinas penanaman modal dan pelayanan terpadu satu pintu (DPMPTSP) Kab. Pulau Morotai, masih dilakukan secara konvensional dengan tahapan yaitu pertama yang harus dilakukan adalah pemohon izin menyerahkan berkas kebagian front office yang bertugas untuk memeriksa berkas jika belum lengkap maka berkas dikembalikan untuk dilengkapi.

Berkas yang sudah lengkap, selanjutnya diserahkan ke sub bagian perizinan untuk memvalidasi data pemohon izin yang telah memenuhi persyaratan. Setelah itu sub bagian perizinan membuat daftar pemohon pembuatan izin, kemudian sub bagian perizinan mencetak laporan validasi dan laporan pemohon sebanyak tiga lembar, lembar pertama diserahkan kepada kepala sub bagian perizinan, lembar kedua disimpan sebagai arsip dan lembar ke tiga diserahkan 
kepada pemohon izin sebagai bukti validasi. Selanjutnya pemohon mendapatkan izin terbit.

Perizinan dibutuhkan ketika akan mendirikan bangunan, usaha dagang, minimarket, praktik dokter, praktik bidan, apotek dan masih banyak lagi jenis perizinan lainnya. Dalam pembuatan perizinan, salah satu hal penting yang perlu diperhatikan adalah masalah persyaratan perizinan.

Permohonan perizinan pada kantor DPMPTSP yang masih bersifat konvensional tersebut sangat membutuhkan banyak biaya dan tenaga bagi pemohon untuk melakukan pengurusan pengajuan izin dengan cara harus datang langsung ke instanti terkait. Sehingga perlu adanya suatu sistem yang memudahkan masyarakat dalam mengakses perizinan tanpa datang langsung ke instansi terkait. Sistem yang dirancang tentunya lebih mudah secara prosedural dalam pengurusan permohonan perizinan dan lebih fleksibel.

\section{LANDASAN TEORI \\ Konsep Dasar Sistem}

Sistem umumnya terdiri dari susunan atas kumpuluan komponenkomponen atau modul-modul yang lebih kecil, yang dikenal dengan sebutan subsistem. Subsistem tersebut menyusun menjadi sebuah sistem, memiliki batasan masing-masing, dan saling berinteraksi untuk mencapai satu tujuan. menghubungkan antar subsistem yang lain yang disebut dengan antarmuka atau penghubung sistem [1].

Sistem sebagai suatu komponen atau variabel yang terorganisir, saling berinteraksi, saling bergantungan satu sama lain dan terpadu [2]. Sistem informasi merupakan suatu sistem di dalam suatu organisasi yang mempertemukan kebutuhan pengolahan transaksi harian yang mendukung fungsi organisasi yang bersifat manajerial dengan kegiatan strategi dari suatu organisasi untuk dapat menyediakan laporan-laporan yang diperlukan oleh pihak luar tertentu [3].

\section{Karakteristik Sistem}

Suatu sistem mempunyai karakteristik tertentu, yaitu mempunyai [1]:

1. Komponen Sistem

2. Batasan Sistem

3. Lingkungan Luar Sistem

4. Penghubung Sistem

5. Masukan Sistem

6. Keluaran Sistem

7. Pengelolaan Sistem

\section{Sistem Informasi}

Sistem informasi merupakan suatu sistem di dalam suatu organisasi yang mempertemukan kebutuhan pengolahan transaksi 
harian, mendukung operasi, bersifat manajerial, dan kegiatan strategi dari suatu organisasi dan menyediakan pihak luar tertentu dengan laporanlaporan yang diperlukan [3].

Sistem informasi juga dikatakan sebagai suatu kombinasi orang, perangkat keras, perangkat lunak, jaringan komunikasi, dan basis data yang mengumpulkan, mengubah, dan menyebarkan informasi dalam suatu bentuk organisasi [4].

\section{Basis Data}

Basis Data atau database didefinisikan sebagai kumpulan data yang terintegrasi dan diatur sedemikian rupa sehingga data tersebut dapat dimanipulasi, diambil, dan dicari secara cepat. Selain berisi data, database juga berisi metadata. Metadata adalah data yang menjelaskan tentang struktur dari data itu sendiri [5]. Basis data berhubungan dengan kumpulan dari tabel-tabel yang saling berelasi, disusun secara logis, sehingga bisa menghasilkan informasi yang bernilai dalam proses pengambilan keputusan [6].

\section{Konsep Dasar Website}

Dalam mencari informasi di internet, pengguna akan menuju ke sebuah alamat unik internet yang disebut nama domain dan menemukan informasi berbentuk teks, gambar diam atau bergerak, animasi bergerak, suara ataupun video dalam sebuah media, yang di sebut dengan website atau situs. Website dibentuk melalui sebua program penjelajah yang berada di sebuah komputer. Web adalah salah satu layanan yang didapat oleh pemakai komputer yang terhubung ke internet [7].

Web merupakan sebuah sistem penyebaran informasi melalui internet. Halaman website biasanya berupa dokumen yang ditulis dalam format Hyper Text Markup Language $\quad(H T M L)$, yang bisa diakses melalui HTTP. HTTP adalah suatu protocol yang menyampaikan berbagai informasi dari server website untuk ditampilkan kepada pada user atau pemakai melalui web browser [8].

\section{Data Flow Diagram (DFD)}

Data Flow Diagram merupakan alat untuk membuat diagram yang serbaguna. DFD terdiri dari notasi penyimpanan data, proses, aliran data, dan sumber masukan (entity) [1]. Berikut simbol DFD yang ditunjukan pada tabel 1 .

Tabel 1. Simbol DFD

\begin{tabular}{|c|lr|}
\hline Simbol & \multicolumn{2}{|c|}{ Fungsi } \\
\hline & $\begin{array}{l}\text { External } \\
\text { mengambarkan } \\
\text { sumber asli ruatu } \\
\text { interaksi, serta } \\
\text { penerimaan akhir dari } \\
\text { sistem }\end{array}$ \\
\hline$\longleftrightarrow$ & $\begin{array}{l}\text { Garis alir, untuk } \\
\text { menggambarkan arus } \\
\text { data yang mengalir }\end{array}$ \\
\hline
\end{tabular}




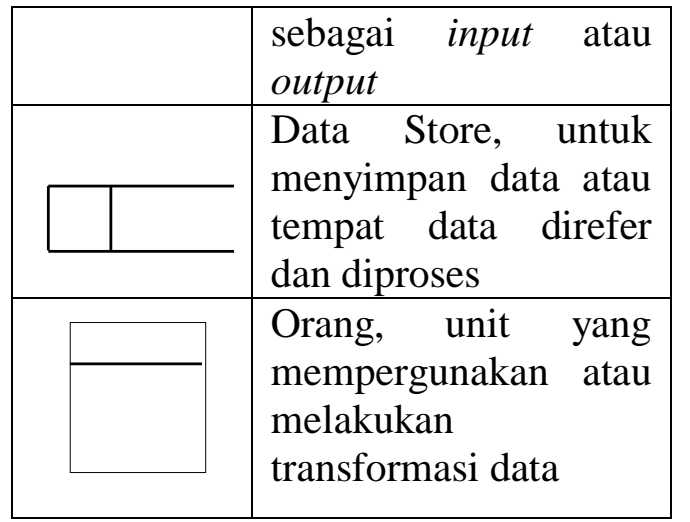

\section{White Box Testing}

Pengujian white box testing dilakukan dengan cara melihat ke dalam modul untuk meneliti kode-kode program yang ada, dan menganalisis apakah ada kesalahan atau tidak. Jika ada modul yang menghasilkan output yang tidak sesuai dengan proses bisnis yang dilakukan, maka baris-baris program, variabel, dan parameter yang terlibat pada unit tersebut akan dicek satu persatu dan diperbaiki, kemudian di-compile ulang [9].

\section{Dinas Penanaman Modal dan Pelayanan Terpadu Satu Pintu Kab. \\ Pulau Morotai}

Dengan ditetapkannya Perda Nomor 7 Tahun 2014, pada tanggal 5 desember 2014 Kabupanten Pulau Morotai telah memiliki Badan Penanaman Modal dan Pelayanan Terpadu Satu Pintu (BPMPTSP) dan akan dipastikan salah satu fungsi kelembagaan Kawasan Ekonomi Khusus (KEK).

Sistem pembuatan izin di dinas penanaman modal dan pelayanan terpadu satu pintu (DPMPTSP) Kab. Pulau Morotai, dengan tahapan yaitu pertama yang harus dilakukan adalah pemohon izin menyerahkan berkas ke bagian front office yang bertugas untuk memeriksa berkas jika belum lengkap maka berkas dikembalikan untuk dilengkapi. Apabila berkas yang sudah lengkap, selanjutnya diserahkan ke sub bagian perizinan untuk memvalidasi data pemohon izin yang telah memenuhi persyaratan. Setelah itu sub bagian perizinan membuat daftar pemohon pembuatan izin, kemudian sub bagian perizinan mencetak laporan validasi dan laporan pemohon sebanyak tiga lembar, lembar pertama diserahkan kepada kepala sub bagian perizinan, lembar kedua disimpan sebagai arsip dan lembar ke tiga diserahkan kepada pemohon izin sebagai bukti validasi. Selanjutnya pemohon mendapatkan izin terbit.

\section{Struktur Organisasi DPMPTSP}

Pada DPMPTPS terdapat struktur organisasi yang mengatur jalannya mekanisme pengurusan perizinan. Gambar 1 menunjukan struktur oganisasi pada DPMPTPS Kab. Pulau Morotai 


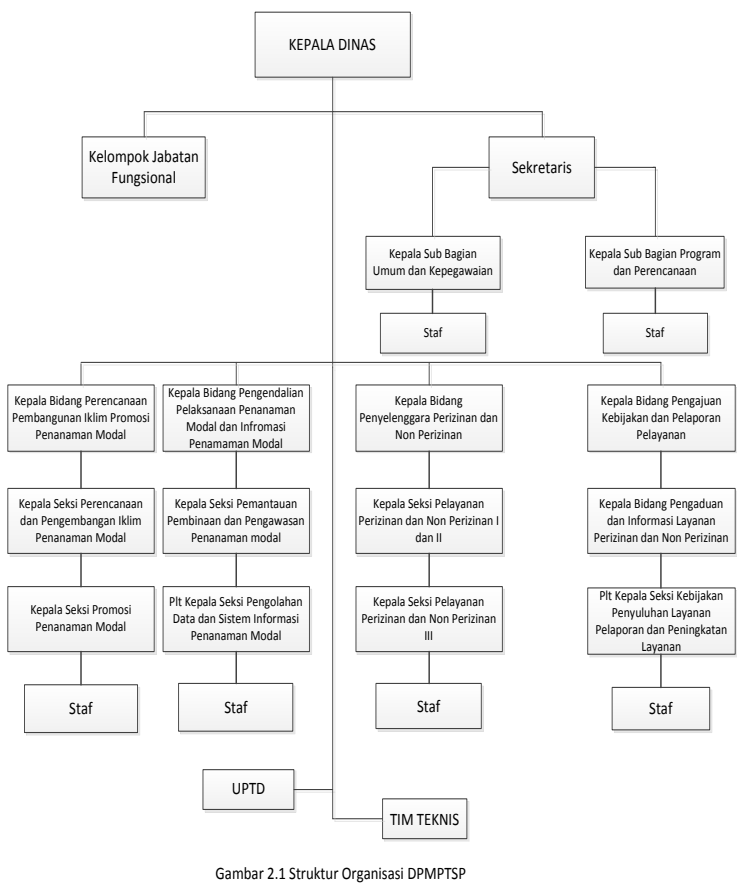

Gambar 1. Struktur Organisasi DPMPTSP

\section{METODE PENELITIAN}

\section{Metode Pengembangan Sistem}

Metode pengembangan sistem yang digunakan adalah metode evolusioner. Metode evolusioner merupakan metode yang dilakukan berdasarkan pada ide untuk mengembangkan implementasi awal kepada pengguna untuk dikomentari dan memperbaikinya versi demi versi sampai sistem yang memenuhi persyaratan diperoleh [9]. Model pengembangan sistem evolusioner ditunjukan pada gambar 2 .

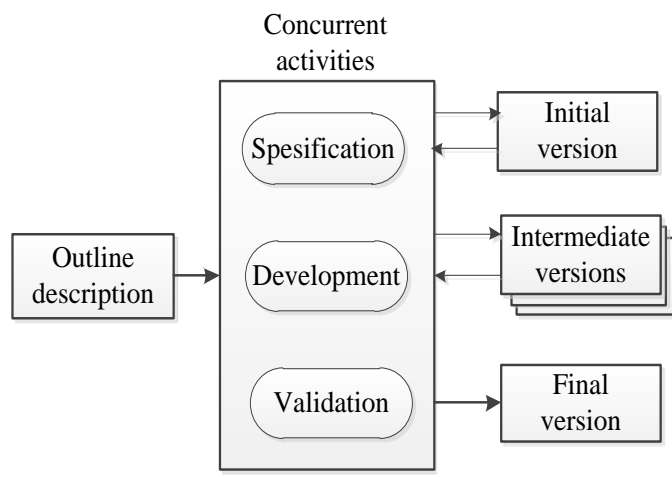

Gambar 2. Model Pengembangan Sistem Evolusioner

\section{Analisa Kebutuhan Sistem}

Kebutuhan sistem yang digunakan dalam pengembangan sebuah sistem perizinan berdasarkan pada kebutuhan kantor DPMPTPS dengan melakukan studi penelitian sesuai dengan kebutuhan yang diperlukan dalam perancangan sistem informasi perizinan agar mudah dioperasikan.

Perancangan sistem informasi perizinan menggunakan baik perangkat lunak maupun perangkat keras diantaranya seperti database menggunakan MySQL dan bahasa pemrograman menggunakan PHP. Sedangkan perangkat keras yang digunakan processor intel core i3 dengan memori $2 \mathrm{~GB}$

\section{Sistem Yang Diusulkan}

Sistem yang diusulkan bertujuan untuk menghasilkan perancangan sistem informasi perizinan yang terkomputerisasi. Usulan perancangan yang dilakukan 
adalah mengimplementasikan sistem perizinan yang masih berupa folder atau arsip menjadi sistem terkomputerisasi. Sistem yang diusulkan berupa:

1. Mulai

2. Pemohon mendownload dan membaca semua persyaratan pembuatan izin

3. Pemohon mengupload data izin sesuai dengan kebutuhan izin pemohon ke dalam sistem dan sistem akan merekam semua data tersebut ke dalam database untuk selanjutnya dikelola oleh admin

4. Pemohon mengisi buku tamu, melihat kontak yang akan dihubungi apabila dalam proses pembuatan izin ada kendala yang dihadapi, pemohon juga dapat membaca informasi berita terbaru terkait dengan dinas perizinan/tentang regulasi yang diterapkan

5. Admin menginput data persyaratan, kontak dan berita sebagai masukan dari pemohon/pengunjung

6. Admin mendapatkan semua data validasi dan informasi dari prosedur dalam bentuk laporan data maupun informasi

7. Selesai.

\section{Diagram Konteks}

Diagram konteks merupakan diagram yang terdiri dari suatu proses dan menggambarkan ruang lingkup suatu sistem [10]. Diagram konteks merupakan level tertinggi dari DFD yang menggambarkan suatu sistem terkait dengan dokumen keluaran dan masukkan serta entitas yang berhubungan dengan sistem. Perancangan sistem DPMPTSP Kab. Pulau Morotai ini berhubungan dengan tiga entitas pengguna, yaitu pemohon dan admin. Diagram konteks ditunjukan pada gambar 3.

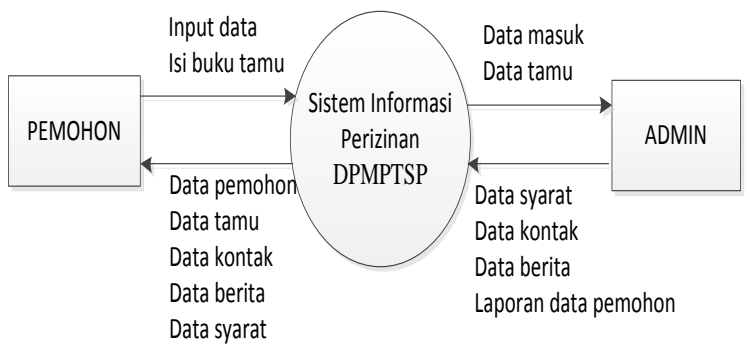

Gambar 3. Digram Konteks Sistem

Perizinan

Pemohon memasukkan datadata ke dalam sistem berupa data pemohon dan isi buku tamu. Sedangkan admin merupakan entitas pengguna sistem yang berhubungan dengan tata kelola sistem.

\section{Diagram Level/Proses}

Diagram

level/proses merupakan uraian proses yang dibuat berdasarkan diagram konteks. Terdapat 3 (tiga) proses yang terjadi dalam sistem, yaitu proses input data, proses rekam data, dan proses menampilkan data. Diagram proses ditunjukan pada gambar 4. 


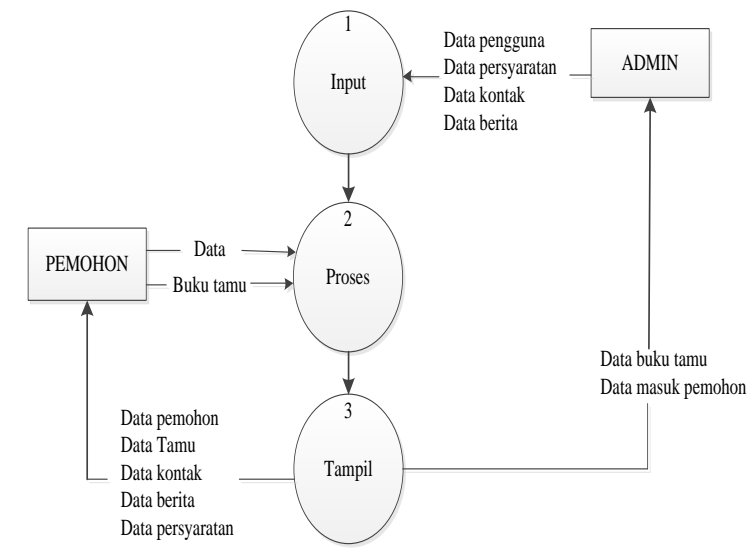

Gambar 4. Digram Level/Proses

\section{Relasi Antar Tabel}

Relasi pada tabel merupakan relasi atau hubungan antara tabel yang satu dengan yang lain pada database. Relasi penting digunakan untuk dapat meminimalisir adanya kesalahan mendesain database. Relasi antar tabel ditunjukan pada gambar 5 .

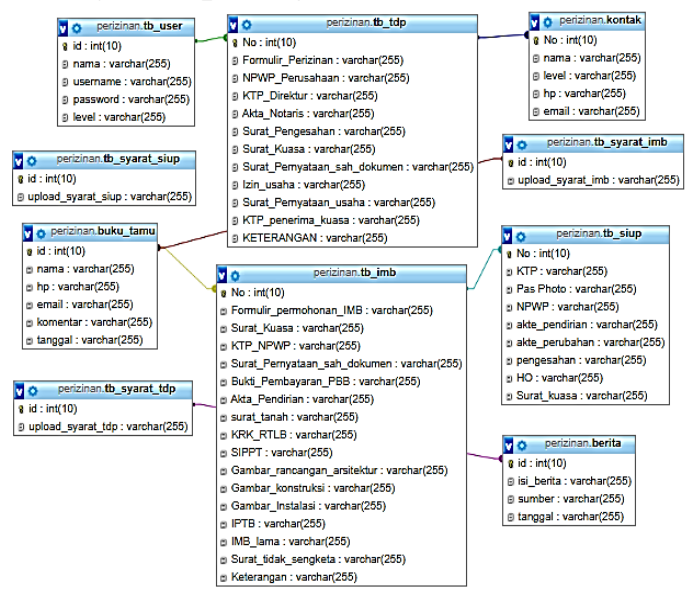

Gambar 5. Relasi Antar Tabel

Sistem Perizinan

\section{HASIL DAN PEMBAHASAN Antar Muka Sistem}

Sistem informasi perizinan pada DPMPTS Kab. Pulau Morotai memiliki dua level pengguna, yaitu pemohon dan admin. Pada Tampilan dashbor terdapat tahapantahapan yang dilakukan untuk dapat masuk pada sistem, sehingga proses data pemohon dengan mudah proses. Seperti pada gambar 6, terdapat tampilan download Persayaratan, pada tampilan ini pemohon dapat melihat secara lengkap persyaratan apa saja yang dibutuhkan untuk pembuatan perizinan dan juga langkah-langkah yang dilakukan oleh pemohon dalam mengusulkan perizinan. Pemohon juga diminta untuk mengisi bukut tamu yang telah yang disiapkan pada tampilan sistem. Apabila pemohon merasa kebingungan dalam mengakses sistem, maka pemohon dapat menghubungi admin yang ada pada tampilan menu kontak yang sudah disedikan.

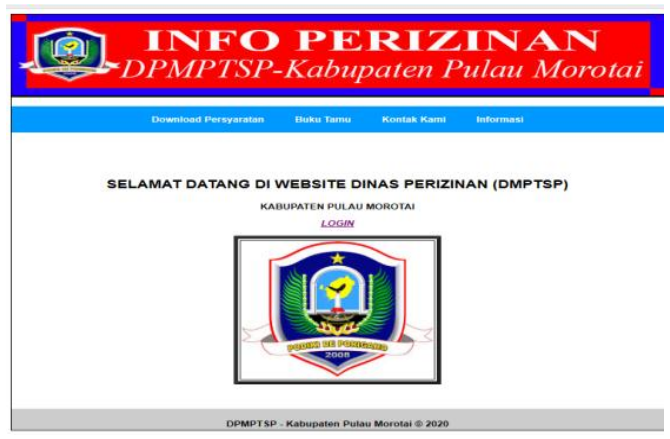

Gambar 6. Tampilan Dashbor Sistem Perizinan

Tampilan untuk pemohon (gambar 7). Setelah pemohon mengetahui persyaratan, pemohon melakukan tahapan registrasi 
sehingga pemohon mendapatkan akun yang di guanakan untuk mengases sistem yang disedikan. pada tahapan selanjutnya, pemohon memasukan username dan password, kemudian pemohon dapat memasukan persyaratan-persyaratan dan secara otomatis persyaratan dokumen perizinan yang diusulkan dapat dilihat oleh admin.

INFO PERIZINAN DPMPTSP-Kabupaten Pulau Morotai

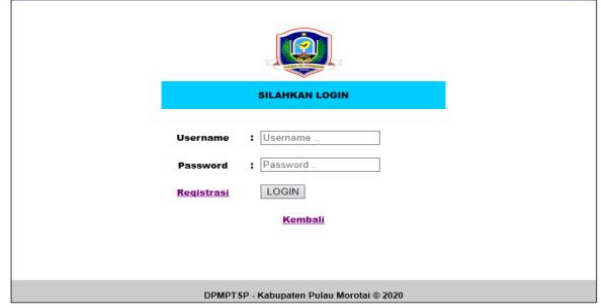

Gambar 7. Tampilan Form Login Pemohon

Pada tampilan gambar 8 , admin memeriksa data pemohon yang telah diusulakn dan ketika terjadi kesalahan dalam penginputan data maupun unggah dokumen, maka admin dapat memperbaiki kesalahan tersebut. Admin juga memulai akses sistem denan memasukkan username dan password. Admin bisa melakukan manipulasi data (tambah, ubah hapus).

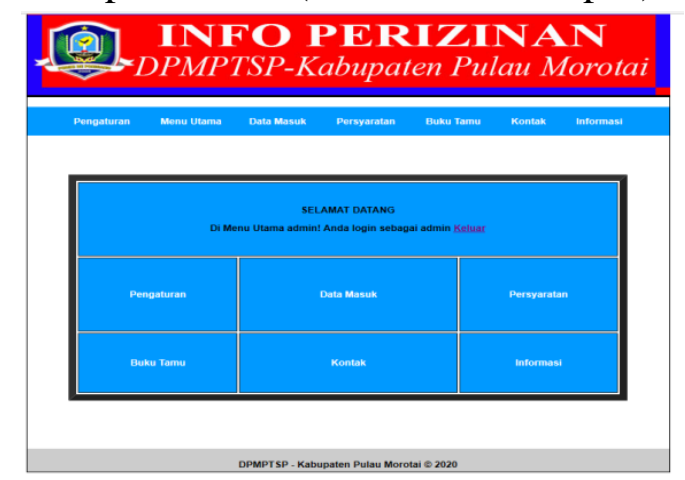

Gambar 8. Tampilan Form

Admin

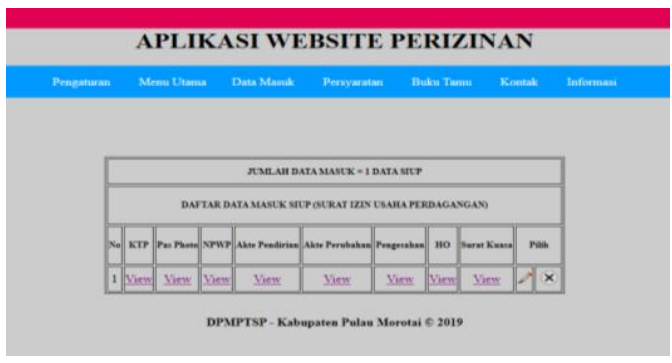

Gambar 9. Tampilan Usulan

Data Surat Izin Usaha Perdagangan (SIUP)

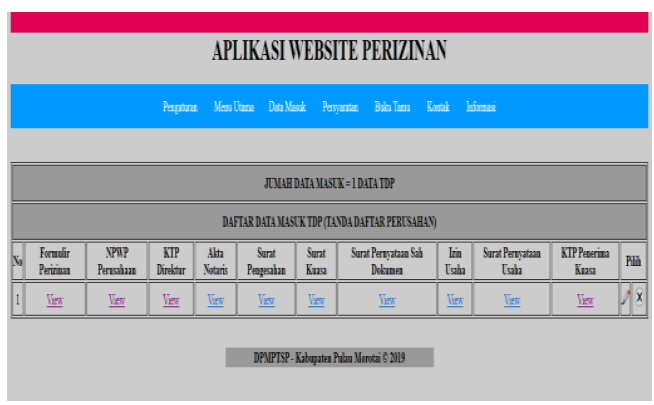

Gambar 10. Tampilan Usulan

Data Tanda Daftar Perusahaan (TDP)

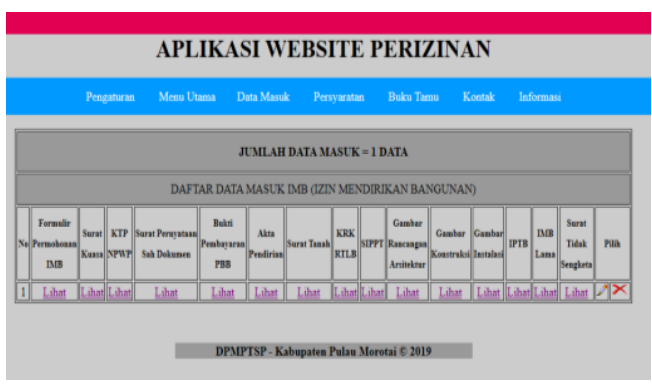

Gambar 11. Tampilan Usulan

Data Izin Mendirikan Bangunan

(IMB)

\section{Pengujian Sistem}

Metode yang digunakan dalam pengembangan sistem untuk 
membangun sistem informasi ini yaitu menggunakan white box testing. Metode white box testing merupakan sebuah perancangan test case (uji kasus) yang mengunakan struktur kontrol yang dijelaskan sebagai bagian dari perancangan perangkat komponen untuk menghasilkan test case [11].

Pengujian white box, disebut juga pengujian glass box, adalah metode desain test case yang menggunakan struktur kontrol desain prosedural untuk memperoleh test case.

Pengujian basic path adalah teknik pengujian white box. Metode ini memungkinkan desainer test case mengukur kompleksitas logis dari desai prosedural dan menggunakannya sebagai pedoman untuk menetapkan basis set dari jalur eksekusi. Test case yang dilakukan untuk menggunakan basis set tersebut dijamin menggunakan setiap statement di dalam program paling tidak sekali selama pengujian.

\section{Hasil Pengujian Program}

Dari hasil pengujian yang dilakukan terlihat kemampuan sistem informasi perizinan pada DPMPTSP Kab. Pulau Morotai berbasisi web dapat ditunjukan pada tabel 2 .

Tabel 2. Analisa Hasil Pengujian Sistem

\begin{tabular}{|c|c|c|c|}
\hline $\begin{array}{c}\text { Nama Bagan } \\
\text { Alir Program }\end{array}$ & $\begin{array}{c}\text { Jumlah } \\
\text { CC }\end{array}$ & $\begin{array}{c}\text { Indepen } \\
\text { dent } \\
\text { Path }\end{array}$ & $\begin{array}{c}\text { Jumlah } \\
\text { Region }\end{array}$ \\
\hline $\begin{array}{l}\text { Pengunjung/ind } \\
\text { ex }\end{array}$ & 7 & 7 & 7 \\
\hline
\end{tabular}

\begin{tabular}{|c|c|c|c|}
\hline $\begin{array}{l}\text { Halaman } \\
\text { pengunjung/ } \\
\text { menu pemohon }\end{array}$ & 4 & 4 & 4 \\
\hline $\begin{array}{l}\text { Pengunjung/do } \\
\text { wnload } \\
\text { persyaratan }\end{array}$ & 2 & 2 & 2 \\
\hline $\begin{array}{l}\text { Pengunjung/Bu } \\
\text { ku Tamu }\end{array}$ & 2 & 2 & 2 \\
\hline $\begin{array}{l}\text { Pengunjung/ko } \\
\text { ntak utama }\end{array}$ & 2 & 2 & 2 \\
\hline $\begin{array}{l}\text { Pengunjung/inf } \\
\text { ormasi }\end{array}$ & 2 & 2 & 2 \\
\hline $\begin{array}{l}\text { Admin/menu } \\
\text { utama }\end{array}$ & 7 & 7 & 7 \\
\hline $\begin{array}{l}\text { Admin/pengatu } \\
\text { ran }\end{array}$ & 2 & 2 & 2 \\
\hline $\begin{array}{l}\text { Admin/data } \\
\text { masuk } \\
\text { pemohon }\end{array}$ & 4 & 4 & 4 \\
\hline $\begin{array}{l}\text { Admin/persyara } \\
\tan \end{array}$ & 3 & 3 & 3 \\
\hline $\begin{array}{l}\text { Admin/buku } \\
\text { tamu }\end{array}$ & 2 & 2 & 2 \\
\hline $\begin{array}{l}\text { Admin/input } \\
\text { kontak }\end{array}$ & 3 & 3 & 3 \\
\hline $\begin{array}{l}\text { Admin/input } \\
\text { informasi }\end{array}$ & 4 & 4 & 4 \\
\hline Total & 44 & 44 & 44 \\
\hline
\end{tabular}

perhitungan diatas didapatkan jumlah Cyclomatic Coplexity (CC) $=44$, Region $=44$ dan Independent Path $=44$. Karena jumlah ketiga parameter ini sama maka dapat disimpulkan bahwa sistem ini telah bebas dari kesalahan logika.

\section{KESIMPULAN}

Dari hasil perancangan hingga proses pengujian yang telah dilakukan pada sistem informasi perizinan pada DPMPTSP Kab. Pulau Morotai berbasis Web menggunakan bahasa pemrograman PHP dengan database menggunakan 
MySQL, sistem dapat meminimalisir kesalahan-kesalahan keterlambatan yang dilakukan dan lebih fleksibel untuk digunakan dengan menunjukan sistem mampu menghasiilkan jumlah cyclomatic coplexity $=44$, region $=44$, dan independent path $=44$.

Perancangan sistem informasi perizinan ini memperjelas prosedur perizinan pada dinas dengan menawarkan sistem informasi perizinan berbasis web dengan memberikan pelayanan yang lebih optimal.

Masyarakat lebih menghemat biaya, tenaga dan mudah dalam mengakses persyaratan, maupun dokumen-dokumen dalam pembuatan surat perizinan tanpa harus datang langsung ke instansi terkait.

\section{DAFTAR PUSTAKA}

[1] Yakub., 2012. Pengantar Sistem Informasi. ISBN 978-979-756807-8, Graha Ilmu, Yogyakarta.

[2] Rosa, A. S dan Shalahuddin, M., 2013. Rekayasa Peragkat Lunak Terstruktur Dan Berorientasi Objek. Informatika, Bandung.

[3] Pressman, R. S., 2012. Rekayasa Perangkat Lunak Edisi 7. Gramedia, Yogyakarta.

[4] O'Brein, J. A., 2005. Pengantar Sistem Informasi. Salemba 4, Jakarta.

[5] Masrur, M., 2016. Pemrograman Web Dinamis Menggunakan Java Server Pages dengan Database
Relasional MySQL. Andi, Yogyakarta.

[6] Ruslan, Takdir., 2014. Laporan Kerja Praktek (Sistem Informasi Koperasi). Fakultas Teknik, Universitas

Muhammadiyah Maluku Utara [7] Sidik, B., 2012. Pemrograman Web dengan PHP. Informatika, Bandung.

[8] Yuhefizar. 2013. Cara Mudah \& Murah Membangun \& Mengelola Website. Graha Ilmu, Yogyakarta.

[9] Fatta, H. A., 2007. Analisis \& Perancangan Sistem

Informasi. ISBN 978-979-29-

0216-7, Andi, Yogyakarta.

[10]Papuangan, M., 2018,

Penerapan Case Based

Reasoning Untuk Sistem

Diagnosis Penyakit Hepatitis.

Jurnal Informatika dan

Komputer (JIKO), 1, 1, 7-12,

ISSN: 2614-8897 (Print)

2656-2945 (Online).

[11] Pressman, R. S., 2010. Software Engineering: A Practitioner's Approach, McGraw-Hill, New York, 68. 